\title{
Bilateral open-angle glaucoma in a young female with Desbuquois syndrome
}

\author{
Isha Chaturvedi ${ }^{1}$, Kumudini Sharma ${ }^{2}$, Vaibhav Jain ${ }^{3}$ \\ From ${ }^{1}$ Senior Resident, ${ }^{2}$ Professor and Head, ${ }^{3}$ Professor, Department of Ophthalmology, SGPGIMS, Lucknow, India
}

\begin{abstract}
Desbuquois dysplasia is characterized by the presence of short stature, short extremities, joint laxity with frequent dislocation, osteopenia, vertebral abnormalities, distinctive facial characteristics, and other abnormalities including myopia and glaucoma. A variant form of Desbuquois type skeletal dysplasia (DBQD), the Kim variant, has also been described and is characterized by short stature, joint, and minor facial anomalies. Here, we report a case of bilateral open-angle glaucoma and high myopia occurring in a young female who presented with Desbuquois syndrome, a rare type of osteochondrodysplasia. The patient presented to the ophthalmology clinic with persistent eye pain and unstable refractive error. Her preliminary examination revealed raised intraocular pressure, high myopia, and skeletal deformities. A complete systemic examination and genetic workup suggested DBQD, Kim variant. With no detailed ophthalmic reports of such patients existing in the literature, it is important that such patients undergo a complete ophthalmic survey to rule out glaucoma, high myopia, and strabismus.
\end{abstract}

Key words: Desbuquois syndrome, Glaucoma, Myopia, Skeletal dysplasia

$\mathrm{D}$ esbuquois syndrome is a rare type of ostochondrodysplasia (a disorder of the development of bones and cartilage) of autosomal recessive inheritance. Desbuquois type skeletal dysplasia (DBQD) is characterized by short stature, generalized joint laxity, short extremities, osteopenia, and distinctive facial anomalies [1]. With the first case being reported by Desbuquois et al. [2] in 1966, there have been fewer than 50 cases reported in the literature. Rarely, these cases may present to the ophthalmologist with a seemingly innocuous complaint such as frequent change of glasses with or without headache. Care must be taken to do a thorough ophthalmic examination for myopic refractive error and glaucoma, and a systemic examination by a physician for other systemic abnormalities.

Here, we report a case of bilateral open-angle glaucoma and high myopia occurring in a young female with Desbuquois syndrome.

\section{CASE REPORT}

A 22-year-old girl was referred to the ophthalmology clinic with persistent eye pain over the past 3 months. She had a history of unstable myopic refractive error over the past 11 years. There was no history suggestive of photopsia, dyschromatopsia, floaters, or scotomas. There were no similar complaints in the family. She

\section{Access this article online}

Received - 04 May 2021

Initial Review - 26 May 2021

Accepted - 08 June 2021

DOI: $10.32677 /$ IJCR.2021.v07.i06.009 was born a full-term baby of non-consanguineous marriage and normal vaginal delivery. At the age of 12 years, she had presented with short stature and bow knees with difficulty in getting up and prolonged standing. At 20 years of age, she presented with menorrhagia. There was no history of antenatal exposure to drugs or alcohol.

Systemic examination showed that she had short stature, short neck, low set ears, mid-facial hypoplasia with a flattened nose bridge, widely spaced teeth with enamel hypoplasia, genu varum, hyperextensibility of small joints of the limbs, and wrist widening (Fig. 1). Ophthalmic examination showed a normal pupillary response. Her best-corrected visual acuity was $6 / 9$ with a myopic correction of -7.75 DS in the right eye and -5.50 DS in the left eye. On slit-lamp examination, both eyes had a normal anterior segment with no angle dysgenesis. The intraocular pressure (IOP) was $34 \mathrm{~mm} \mathrm{Hg}$ and $32 \mathrm{~mm} \mathrm{Hg}$ in the right and left eye, respectively. The optic disc showed inferonasal crescent of peripapillary atrophy and a vertical cup-to-disc ratio of 0.6 in both eyes. A 30-2 visual field showed a generalized reduction in sensitivity in both eyes. The central corneal thickness was 380 um and $382 \mathrm{um}$ in the right and left eye, respectively. She was diagnosed as having bilateral open-angle glaucoma (Fig. 2).

Her skeletal survey revealed platyspondyly, rounded iliac wings with a small acetabulum, and metaphyseal abnormalities of the digits (Figs. 3 and 4). Based on the above clinical and radiological findings, she was diagnosed as a case of Desbuquois dysplasia, Kim type.

Correspondence to: Isha Chaturvedi, 17, Vishnulok colony, Kanpur Road, Lucknow - 226 012, Uttar Pradesh, India. E-mail: ishachats.90@gmail.com

(C) 2021 Creative Commons Attribution-NonCommercial 4.0 International License (CC BY-NC-ND 4.0). 
The patient was started on bisphosphonates, oral calcium, vitamin D supplements, and brimonidine eye drops. At present, she is on 6-monthly follow-ups in the medical genetics and ophthalmology departments. On subsequent visits, her IOP reduced to 16- and 14-mm $\mathrm{Hg}$, respectively, and she was tolerating her refractive correction well.

\section{DISCUSSION}

Desbuquois dysplasia is a rare autosomal recessive type of osteochondrodysplasia with $<50$ cases reported in the literature. Two forms have been distinguished on the basis of the presence (type 1) or the absence (type 2) of characteristic hand anomalies. A variant form of DBQD, the Kim variant, has also been described and is characterized by short stature, joint, and minor facial anomalies, with significant hand anomalies with short bones in the hands, long fingers, and advanced bone age. DBQD type 1 and Kim variant are caused by mutations in the gene CANT1 [2].

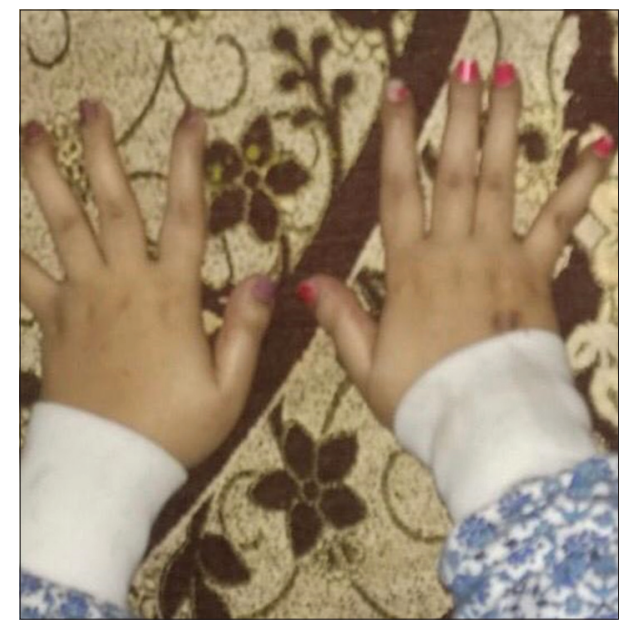

Figure 1: Appearance of hands in DBQD
Its well-recognized features are intrauterine growth retardation, micromelic dwarfism, generalized joint laxity, hand abnormalities, narrow chest, kyphoscoliosis, facial dysmorphism, and varying degrees of mental retardation. There have been occasional remarks of open-angle glaucoma and myopia in a few case reports. However, a detailed ophthalmic case report of bilateral open-angle glaucoma and high myopia has never been documented as far as the knowledge of the authors is concerned.

This kind of dysplasia was first reported by Desbuquois et al. in 1966 in two siblings with short stature, multiple joint dislocations, disorganized calcification in hands and feet, and mental retardation. One of these patients had bilateral openangle glaucoma and prominent eyes since birth [2]. Le merrer et al. reported five cases of Desbuquois dysplasia of which two had a "wide-eyed" appearance and one had blue sclerae [3]. Maroteaux et al. reported a new type of skeletal dysplasia with severe dwarfism and moderate to severe visual impairment from glaucoma [4]. In 2004, Faivre et al provided follow-up of four patients with Desbuquois syndrome, aged 16-22 years. Of these, only one patient was reported to have severe myopia and acute open-angle glaucoma at the age of 17 years which required urgent surgery [5]. Faden et al. (2010) reported a male infant with Desbuquois dysplasia who also had bilateral open-angle glaucoma [6]. Laccone et al. reported three cases of a severe form of Desbuquois syndrome with death in-utero. These cases had upslanting eyes with proptosis and epicanthal folds [7]. Singh et al. (2015) reported the Kim variant of Desbuquois dysplasia in three Indian patients, however, ophthalmic features were not reported in any of them [8]. There was one rare case report of Kim type of dysplasia in an Indian patient by Agrawal et al. where glaucoma and myopia were reported [9]. These studies are summarized in Table 1.

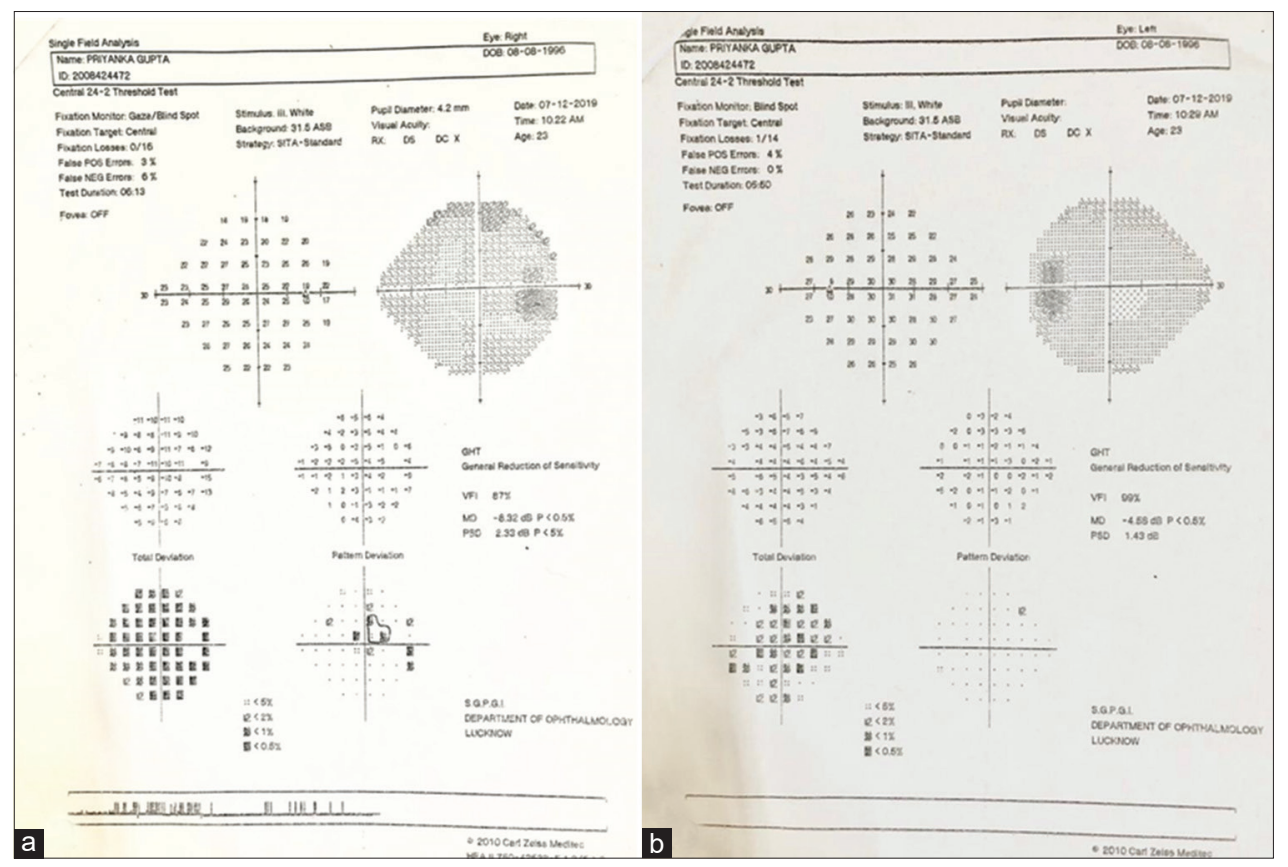

Figure 2: Visual field assessment suggestive of early glaucoma in the (a) right eye and (b) generalized reduction of sensitivity in the left eye (an early sign of glaucoma) 
Table 1: Previously reported cases of Desbuquois syndrome with ophthalmic finding

\begin{tabular}{|c|c|c|c|c|c|}
\hline Study & Age/Sex & General features & Glaucoma & $\begin{array}{l}\text { Other ophthalmic } \\
\text { features }\end{array}$ & Intervention \\
\hline $\begin{array}{l}\text { Desbuquois et al. } \\
(1966)[2]\end{array}$ & $\begin{array}{l}8 \text { years and } 20 \\
\text { months }\end{array}$ & $\begin{array}{l}\text { Short stature, multiple joint dislocations, } \\
\text { disorganized calcification in hands and } \\
\text { feet, mental retardation }\end{array}$ & + & Prominent eyes & -- \\
\hline $\begin{array}{l}\text { Le merrer et al. } \\
\text { (1991)[3] }\end{array}$ & $2-7$ years & $\begin{array}{l}\text { Short stature, Hyperlaxity, round face, } \\
\text { micrognathia, short narrow thorax, } \\
\text { osteoporosis, prominent lesser trochanter, } \\
\text { metaphyseal enlargement, advanced } \\
\text { bone age, supernumerary carpal bones, } \\
\text { large or double thumb, dislocation of } \\
\text { the knees and hips, deviation of fingers, } \\
\text { platyspondyly }\end{array}$ & $\begin{array}{l}? \\
\text { Not known }\end{array}$ & Prominent eyes & -- \\
\hline $\begin{array}{l}\text { Maroteaux et al. } \\
(1996)[4]\end{array}$ & $\begin{array}{l}\text { Case } 1-8 \\
\text { years, female } \\
\text { Case } 2-6 \\
\text { months, male }\end{array}$ & $\begin{array}{l}\text { Dwarfism, flat face, cleft palate, } \\
\text { enlarged metaphyses, short long bones, } \\
\text { flat vertebrae } \\
\text { Similar to Case } 1\end{array}$ & + & $\begin{array}{l}\text { Corneal opacities, } \\
\text { severe ocular } \\
\text { impairment } \\
\text { Iridocorneal } \\
\text { dysgenesis, moderate } \\
\text { ocular impairment }\end{array}$ & -- \\
\hline $\begin{array}{l}\text { Faivre et al. } \\
(2004)[5]\end{array}$ & $\begin{array}{l}16-22 \text { years, } 3 \\
\text { male, } 1 \text { female }\end{array}$ & $\begin{array}{l}\text { Short stature of prenatal onset, joint } \\
\text { laxity, facial alterations, 'Swedish key' } \\
\text { appearance of proximal femur, advanced } \\
\text { carpal and tarsal bone age; hand } \\
\text { abnormalities in only one case }\end{array}$ & $\begin{array}{l}+(\text { only } \\
\text { Case 1) }\end{array}$ & $\begin{array}{l}\text { Prominent bulging } \\
\text { eyes and severe } \\
\text { myopia }\end{array}$ & $\begin{array}{l}\text { Needed surgery } \\
\text { at } 17 \text { years due to } \\
\text { acute open angle } \\
\text { glaucoma }\end{array}$ \\
\hline $\begin{array}{l}\text { Faden et al. } \\
(2010)[6]\end{array}$ & -- & $\begin{array}{l}\text { Micromelia, growth retardation, clubfeet, } \\
\text { dysmorphic face, hypotonia, short neck, } \\
\text { wide nipples and protuberant abdomen }\end{array}$ & + & -- & -- \\
\hline $\begin{array}{l}\text { Lacone et al. } \\
(2011)[7]\end{array}$ & $\begin{array}{l}\text { Male fetuses } \\
\text { at } 25,21 \text { and } \\
17 \text { weeks of } \\
\text { gestation }\end{array}$ & $\begin{array}{l}\text { Brachymelic dwarfism, hydropic, short } \\
\text { neck and trunk, distended abdomen, } \\
\text { large cranium with high forehead, short } \\
\text { mid face, broad nose, microstomia, } \\
\text { microretrognathia }\end{array}$ & $\begin{array}{l}? \\
\text { Not known }\end{array}$ & $\begin{array}{l}\text { Upslanted eyes } \\
\text { with proptosis and } \\
\text { epicanthal folds }\end{array}$ & $\begin{array}{l}\text { Termination of } \\
\text { pregnancy due } \\
\text { to severe form } \\
\text { of Desbuquois } \\
\text { syndrome }\end{array}$ \\
\hline Agrawal et al. (2021)[9] & $\begin{array}{l}\text { Case report }-20 \\
\text { years, female }\end{array}$ & $\begin{array}{l}\text { Short stature, short neck, low set ears, } \\
\text { mid-facial hypoplasia, metaphyseal } \\
\text { abnormalities of the digits, menorrhagia, } \\
\text { delayed motor milestones, glaucoma } \\
\text { and myopia }\end{array}$ & + & $\begin{array}{l}\text { Bilateral high myopia } \\
\text { Blue sclera }\end{array}$ & -- \\
\hline
\end{tabular}

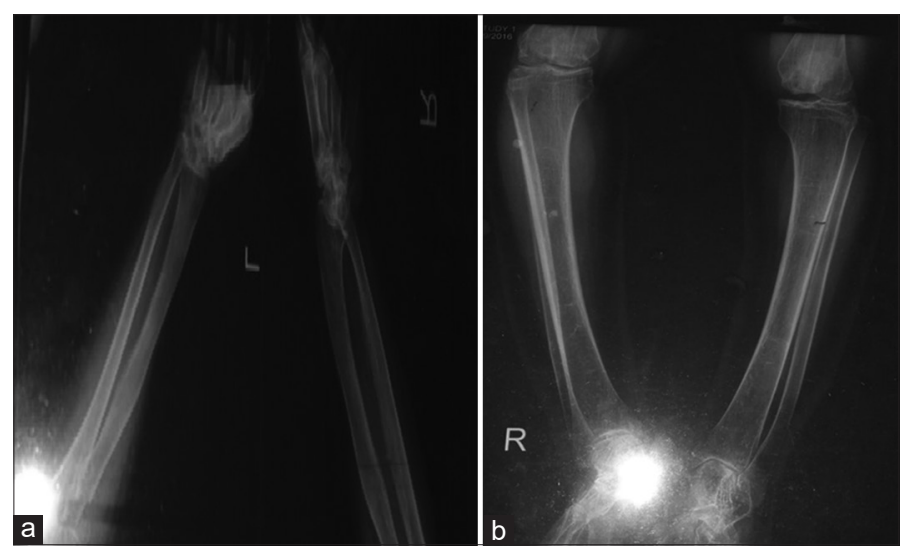

Figure 3: X-ray of (a) hands showing metaphyseal abnormalities and wrist widening; (b)lower limbs showing genu varum

To the best of our knowledge, this is the first ophthalmic case report of bilateral primary open-angle glaucoma in an adult with Desbuquois syndrome. The patient did not have angle dysgenesis and her anterior segment was normal. However, she had bilateral

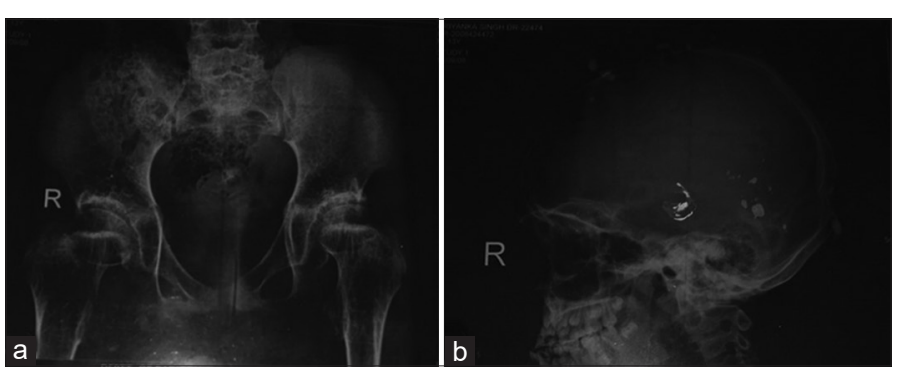

Figure 4: (a) X-ray of hip joint showing small acetabulum and rounded iliac wings; (b) Lateral $X$ ray of skull showing mid-face hypoplasia and widely spaced teeth

high myopia. Her IOP was raised and her cup-to-disc ratio and visual fields were suggestive of glaucoma. She was started on brimonidine eyedrops which brought down her IOP to normal. At present, she is in follow-up for the past two years with no new ocular complaints.

Our study emphasizes the importance of regular ophthalmic follow-up in patients presenting with skeletal dysplasias keeping 
in mind the high prevalence of open-angle glaucoma in such patients.

\section{CONCLUSION}

Desbuquois syndrome is a rare clinical entity that is known to present with ocular features of glaucoma, high myopia, and strabismus. A high index of suspicion is needed while examining such patients so that timely control of intraocular pressure is done.

\section{REFERENCES}

1. Desbuquois Dysplasia. Available from: https://www.omim.org/ entry/251450. [Last accessed on 2020 Nov].

2. Desbuquois G, Grenier B, Michel J, Rossignol C. Nanisme chondrodystrophique avec ossification anarchique et polymalformations chez deux soeurs. Arch Fr Pediat 1966;23:573-87.

3. Le Merrer M, Young ID, Stanescu V, Maroteaux P. Desbuquois syndrome. Eur J Pediatr 1991;150:793-6.
4. Maroteaux P, Manouvrier S, Bonaventure J, Le Merrer M. Dyssegmental dysplasia with glaucoma. Am J Med Genet 1996;63:46-9.

5. Faivre L, Cormier-Daire V, Young I, Bracq H, Finidori G, Padovani JP, et al. Long-term outcome in Desbuquois dysplasia: A follow-up in four adult patients. Am J Med Genet 2004;124A:54-9.

6. Faden M, Al-Zahrani F, Arafah D, Alkuraya F. Mutation of CANT1 causes Desbuquois dysplasia. Am J Med Genet 2010;152A:1157-60.

7. Laccone F, Schoner K, Krabichler B, Kluge B, Schwerdtfeger R, Schulze B, et al. Desbuquois dysplasia Type I and fetal hydrops due to novel mutations in the CANT1 gene. Eur J Hum Genet 2011;19:1133-7.

8. Singh A, Kim OH, Iida A, Park WY, Ikegawa S, Kapoor S. A novel CANT1 mutation in three Indian patients with Desbuquois dysplasia Kim type. Eur J Med Genet 2015;58:105-10.

9. Agrawal N, Srivastava P, Phadke SR. Desbuquois dysplasia Kim variant: A rare case report syndrome. Clin Dysmorphol 2021;30:62-5.

Funding: None; Conflicts of Interest: None Stated.

How to cite this article: Chaturvedi I, Sharma K, Jain V. Bilateral open-angle glaucoma in a young female with Desbuquois syndrome. Indian J Case Reports. 2021;7(6):247-250. 